\title{
Thermal Testing of the Proposed HUD Energy Efficiency Standard for New Manufactured Homes
}

Ronald D. Judkoff

Gregory M. Barker

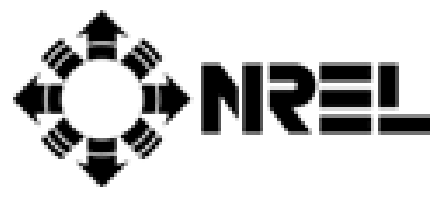

National Renewable Energy Laboratory 1617 Cole Boulevard Golden, Colorado 80401-3393

A national laboratory of the U.S. Department of Energy Managed by Midwest Research Institute for the U.S. Department of Energy under contract No. DE-AC36-83CH10093

June 1992 


\section{Thermal Testing of the Proposed HUD Energy Efficiency Standard for New Manufactured Homes}

Ronald D. Judkoff

Gregory M. Barker

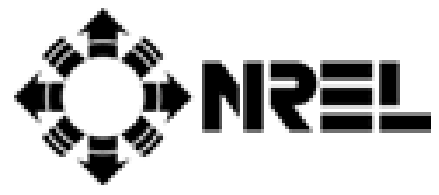

National Renewable Energy Laboratory 1617 Cole Boulevard Golden, Colorado 80401-3393

A national laboratory of the U.S. Department of Energy Managed by Midwest Research Institute for the U.S. Department of Energy under contract No. DE-AC36-83CH10093

Prepared under Task No. AS575440

June 1992 


\section{NOTICE}

This report was prepared as an account of work sponsored by an agency of the United States government. Neither the United States government nor any agency thereof, nor any of their employees, makes any warranty, express or implied, or assumes any legal liability or responsibility for the accuracy, completeness, or usefulness of any information, apparatus, product, or process disclosed, or represents that its use would not infringe privately owned rights. Reference herein to any specific commercial product, process, or service by trade name, trademark, manufacturer, or otherwise does not necessarily constitute or imply its endorsement, recommendation, or favoring by the United States government or any agency thereof. The views and opinions of authors expressed herein do not necessarily state or reflect those of the United States government or any agency thereof. 


\begin{abstract}
Thermal testing of two manufactured homes was performed at the National Renewable Energy Laboratory's (NREL's) Collaborative Manufactured Buildings Facility for Energy Research and Testing (CMFERT) environmental enclosure in the winter and spring of 1991. The primary objective of the study was to directly measure the thermal performance of the two homes, each built according to a proposed new U.S. Department of Housing and Urban Development (HUD) standard (1). Secondary objectives were to test the accuracy of an accompanying compliance calculation method and to help manufacturers find cost-effective ways to meet the new standard (2). Both homes performed within the standard without major design or production line modifications. Their performance fell within $8 \%$ of predictions based on the new draft HUD calculation manual; however, models with minimum window area were selected by the manufacturer. Models with more typical window area would have required substantive design changes to meet the standard. Several other tests were also performed on the homes by both NREL and the Florida Solar Energy Center (FSEC) to uncover potential thermal anomalies and to explore the degradation in thermal performance that might occur because of (a) penetrations in the rodent barrier from field hookups and repairs, (b) closing of interior doors with and without operation of the furnace blower, and (c) exposure to winds.
\end{abstract}




\section{Table of Contents}

$\underline{\text { Page }}$

1.0 Background $\ldots \ldots \ldots \ldots \ldots \ldots \ldots \ldots \ldots \ldots \ldots \ldots \ldots \ldots \ldots \ldots \ldots \ldots$

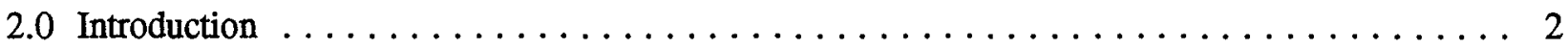

3.0 General Testing Procedures $\ldots \ldots \ldots \ldots \ldots \ldots \ldots \ldots \ldots \ldots \ldots \ldots \ldots \ldots \ldots \ldots \ldots \ldots$

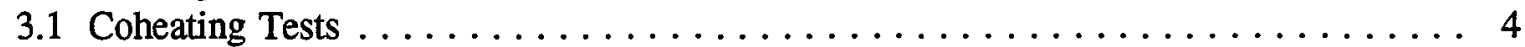

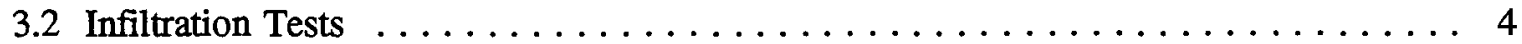

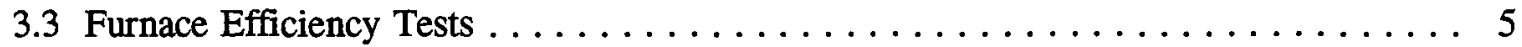

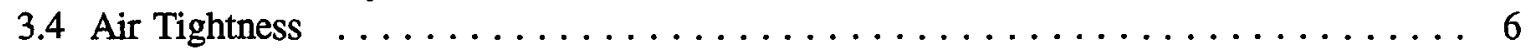

4.0 Results $\ldots \ldots \ldots \ldots \ldots \ldots \ldots \ldots \ldots \ldots \ldots \ldots \ldots \ldots \ldots \ldots \ldots \ldots \ldots$

4.1 Compliance With Proposed Standard $\ldots \ldots \ldots \ldots \ldots \ldots \ldots \ldots \ldots \ldots \ldots$

4.2 Sensitivity of Thermal Performance $\ldots \ldots \ldots \ldots \ldots \ldots \ldots \ldots \ldots \ldots \ldots$

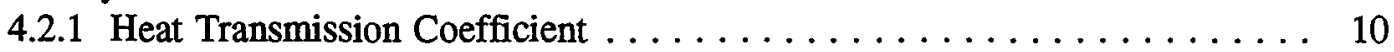

4.2 .2 Furnace Efficiency $\ldots \ldots \ldots \ldots \ldots \ldots \ldots \ldots \ldots \ldots \ldots \ldots$

4.2 .3 Air Tightness . . . . . . . . . . . . . . . . . 14

5.0 Infrared Thermography $\ldots \ldots \ldots \ldots \ldots \ldots \ldots \ldots \ldots \ldots \ldots \ldots \ldots \ldots \ldots$

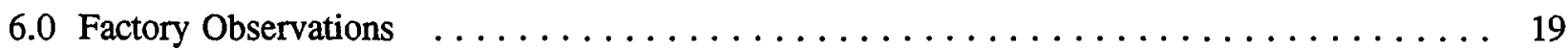

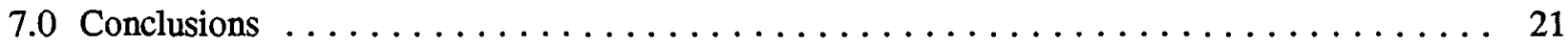

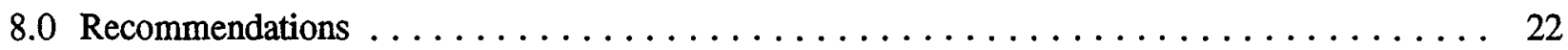

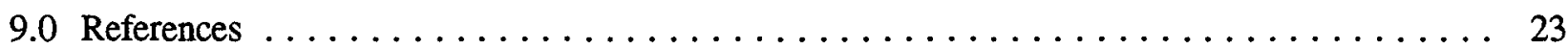

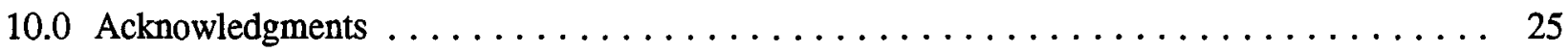




\section{List of Figures}

$\underline{\text { Page }}$

Figure 1. Cold-home tracer test for February $14,1991 \ldots \ldots \ldots \ldots \ldots \ldots \ldots \ldots$

Figure 2. Comparison of measured-to-calculated overall heat loss coefficients for both homes $\ldots .8$

Figure 3. Results of varying several parameters that affect thermal performance of

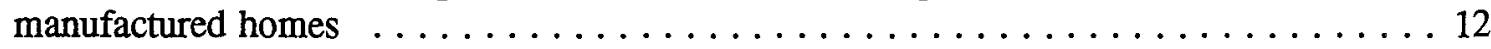

Figure 4. Effects on furnace efficiency of varying several parameters that affect thermal

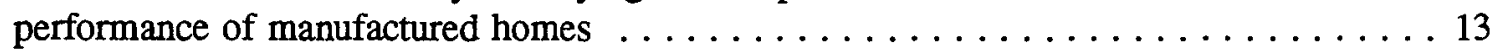

Figure 5. Results of blower-door tests on several new Schult homes $\ldots \ldots \ldots \ldots$

\section{List of Tables}

Table 1: Exterior Film Resistances Specified in HUD Compliance Manual $\ldots \ldots \ldots \ldots \ldots$

Table 2. Thermal Characteristics of Test Homes $\ldots \ldots \ldots \ldots \ldots \ldots \ldots \ldots$

Table 3. Parameters Tested in Sensitivity Study $\ldots \ldots \ldots \ldots \ldots \ldots \ldots \ldots \ldots \ldots$

Table 4. FSEC "Duct Blaster" Results $\ldots \ldots \ldots \ldots \ldots \ldots \ldots \ldots \ldots \ldots \ldots \ldots$

Table 5: Pressure Difference Inside to Outdoors $\ldots \ldots \ldots \ldots \ldots \ldots \ldots \ldots \ldots$ 


\subsection{Background}

In 1987 Congress passed legislation that required the U.S. Department of Housing and Urban Development (HUD) to revise its energy conservation standard for manufactured housing. HUD developed a proposed modification of the existing Manufactured Home Construction and Safety Standards (MFCSS) that consisted of a computer-generated revision to the maximum conduction heat transmission coefficient (which HUD calls the $U_{0}-$ Value, but which we call the $U_{0, c}-$ Value to emphasize that it does not include infiltration) specified in Section F (3280.506) of the MHCSS. We define these terms as:

$$
\mathrm{U}_{\mathrm{o}, \mathrm{c}}=\mathrm{UA}_{\mathrm{c}} / \mathrm{A}_{\mathrm{c}}
$$

where: $\quad \mathrm{UA}_{\mathrm{c}}=$ total heat loss not including infiltration, Btu/hr ${ }^{\circ} \mathrm{F}$

$A_{c}=$ total conductive heat loss surface area, $\mathrm{ft}^{2}$

$\mathrm{U}_{\mathrm{o}}=$ overall heat transmission coefficient including infiltration (HUD's definition of this term is exactly equivalent to our definition of $U_{0, c}$ )

$\mathrm{U}_{\mathrm{o}, \mathrm{c}}=$ overall heat transmission coefficient not including infiltration

HUD also developed a revised calculation procedure by which manufacturers must show compliance with the new standard.

Recognizing that a computer model cannot account for all heat transfer mechanisms, HUD commissioned the National Renewable Energy Laboratory (NREL) in the fall of 1991 to conduct a series of thermal tests on two prototypical homes constructed to meet the standard in two climatic zones. The work was conducted under auspices of the Department of Energy/HUD Initiative, a joint working agreement between these two departments. 


\subsection{Introduction}

For several years NREL had been testing the thermal effectiveness of retrofits for manufactured buildings under DOE's National Weatherization Program. As a result, test facilities and short-term test methods had been developed that allow rapid and accurate determination of the overall U-Value $\left(U_{0}\right)$ of manufactured buildings in a large-scale environmental chamber $(3,4,5,6)$. This method is also appropriate for testing new manufactured buildings, or any building that is designed to be easily transported and assembled on a nonpermanent foundation, and that can fit inside the environmental chamber.

In the fall of 1990, NREL arranged via the Manufactured Housing Institute (MHI) to collaborate with Schult Inc. Schult agreed to build two homes, one to a proposed "cold-zone" standard and one to a proposed "warm-zone" standard. The zones were deliberately kept vague in accordance with government regulations to prevent Schult from gaining "prior knowledge," because at that time the standard had not been released for public review (7). The ground rules of the collaborative project were as follows:

a) Schult was allowed to choose any one of their typical single-wide models as the base to which energy improvements, required to meet the new standard, would be applied. Schult insisted on this approach because they would have to sell the homes on the open market once the 3-month testing period was completed. This also suited our purposes because we recognized that homes meeting the new standard should be as marketable as typical current homes.

b) The cold-zone and warm-zone homes would be identical except for changes required by the different target $\mathrm{U}_{\mathrm{o}, \mathrm{c}}$-Values.

c) We did not try to influence the design of the homes. Schult was encouraged to meet the standard in the most cost-effective way they thought possible.

d) NREL observed the homes being built in the factory, and documented the "as-built" construction details and specifications.

e) Schult calculated compliance with the new standards for their designs using the draft calculation manual for the new calculation method.

f) We recalculated compliance with the new standards using the same method as Schult, but based on the as-built specifications instead of the design specifications.

g) We tested the homes.

The objectives of the tests were to:

- Directly measure the actual as-built heat transmission coefficients of the homes

- Determine if the homes met the standard

- Determine how easy, or difficult, it was for the manufacturer to meet the standard. For example, did they have to make significant alteration to their standard designs or production line operations?

- Determine the accuracy of the new HUD calculation method in predicting the heat transmission coefficients of the homes. 
In actual use, many heat transfer paths not taken into account by the standard, or its associated compliance calculation method, are likely to be operative. We therefore conducted some additional tests to expose potential thermal anomalies and to investigate the degradation in thermal performance that might occur because of (a) penetrations in the rodent barrier from field hookups and repairs, (b) duct leaks, (c) closing of interior doors with and without operation of the furnace blower, and (d) exposure to winds. We selected these particular phenomena because older mobile homes tested during our work for the National Weatherization Program had been particularly vulnerable in those areas. Also, recent observations in sitebuilt homes with forced air distribution systems had indicated that duct leaks, the forced air blower, and interior door closures can significantly affect infiltration rates and energy usage (8).

We investigated these issues using coheating, tracer gas, blower door, and infra-red imaging techniques. These methods are described briefly in the next section. More detailed descriptions can be found in references $3,4,5$ and 6 . 


\subsection{General Testing Procedures}

\subsection{Coheating Tests}

NREL's Collaborative Manufactured Buildings Facility for Energy Research and Testing (CMFERT) consists of a large insulated warehouse in which a manufactured home can be placed. The warehouse is equipped with computer-controlled heaters that can be set to maintain the warehouse temperature at a steady value. The test home is then heated with electric heaters, while a computer-controlled thermostat maintains the interior temperature of the home at any desired value. This method, commonly referred to as a "coheating" test, allows the manufactured home to achieve a steady-state condition, with the warehouse temperature acting as the "outside" temperature. An overall UA value of the home is then calculated:

$$
\mathrm{UA}=\mathrm{Q}_{\mathrm{ss}} / \Delta \mathrm{T} \quad\left(\mathrm{Btw} / \mathrm{hr}{ }^{\circ} \mathrm{F}\right)
$$

where:

$\mathrm{Q}_{\text {ss }}=$ heat input of heaters under steady state (Btu/hr)

$\Delta \mathbf{T}=$ average difference in temperature between home and warehouse $\left({ }^{\circ} \mathrm{F}\right)$

Three vertical rakes of three thermocouples each, placed in the two end zones and the central zone of the home, were used to measure the interior temperatures. The average of these defined the average internal temperature of the home. Heater placement and power were adjusted to keep these three temperature profiles as even as possible. The warehouse temperatures were taken in a similar way except that the top sensor of each rake was placed at the same height as the ridge-line of the test home roof.

\subsection{Infiltration Tests}

Infiltration rates during the tests were measured using an ASTM 1983 tracer gas decay technique, in which a small amount of a nontoxic gas was injected into the home, and the decay in its concentration was measured over time (9). This gave an indication of the rate at which air inside the home was replaced by outside air. This method uses an exact solution of the tracer gas mass balance equation. However, the method assumes (a) perfect mixing of the tracer gas with inside air, and (b) no accumulation of gas outside the home. We measured concentrations in the warehouse (our outside) during several tests to be certain that no gas was accumulating. Little is known about the magnitude of errors caused by imperfect mixing. Because we had the advantage of doing our decay tests under nonchanging conditions of wind and temperature (steady-state infiltration), we were able to analyze the variability and repeatability of the tracer decay technique. Figure 1 shows an initial period of instability in the test data lasting for about 2 hours (probably caused by imperfect mixing). After this period the average result remains quite steady for the duration of the test with a trend toward increased high-frequency noise as the rate of decay in gas concentration becomes very small toward the end of the test period. In general we observed a repeatability of about $+-10 \%$ with this technique. This was sufficiently accurate for these relatively airtight homes in which infiltration was usually less than about $5 \%$ of the building overall heat loss.

Studies have shown that, depending on the geometry of the cracks where infiltration occurs, some heat is actually recovered as the warm air passes out of the building (10). This effect has been shown to increase as cracks get tighter, and as the path length followed by the air lengthens. For this reason, an "infiltration heat recovery factor" of 0.5 was assumed in converting the air exchange rates measured with 


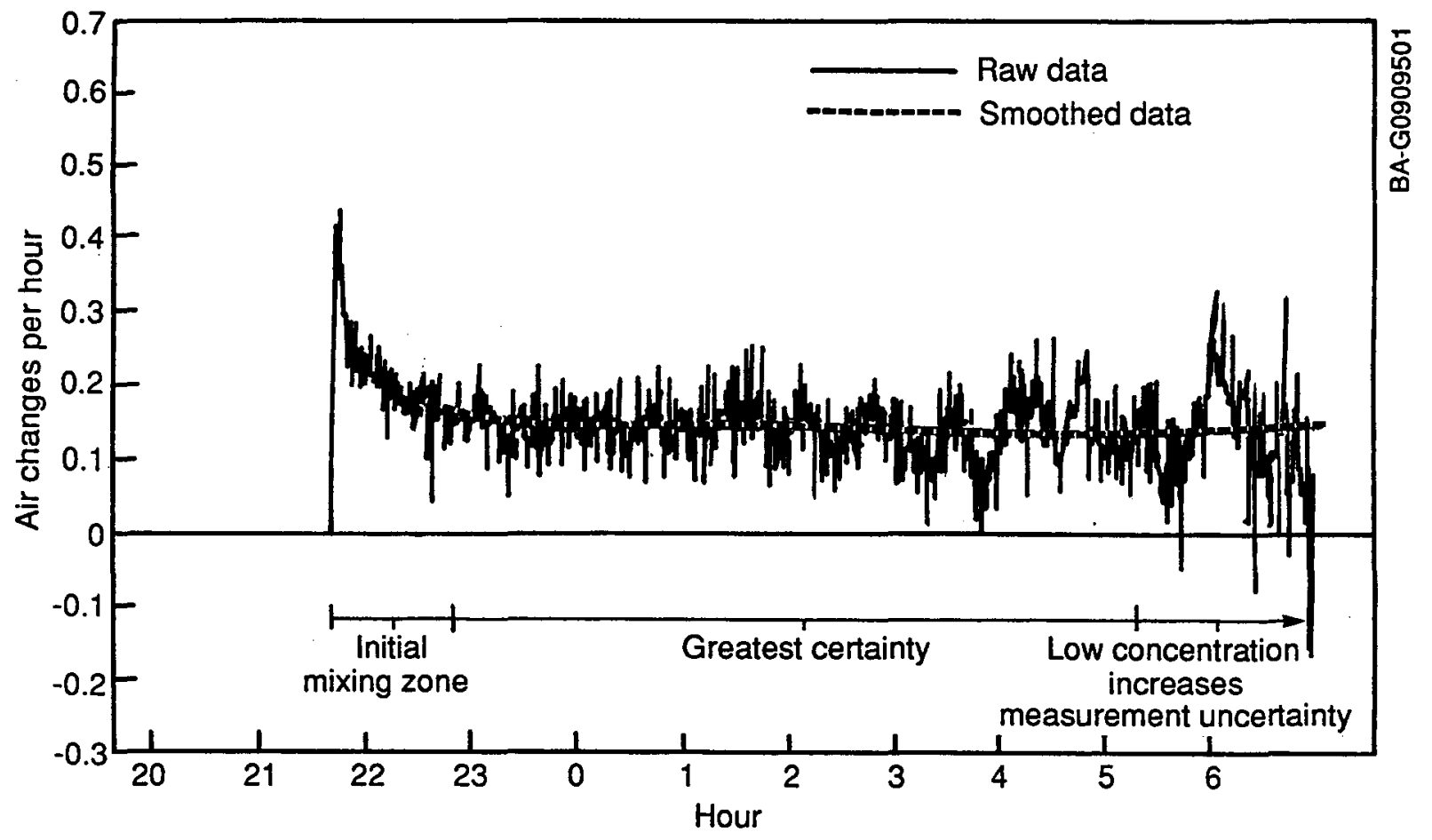

Figure 1. Cold-home tracer test for February 14, 1991

tracer tests to energy losses. For example, if the infiltration rate was measured to be 0.2 air changes per hour $(\mathrm{ACH})$, it was assumed that the actual heat loss due to the infiltration was equal to:

$$
\mathrm{Q}_{\text {inf }} \quad=\quad 0.5 *\left(0.2 \rho \mathrm{C}_{\mathrm{p}} \mathrm{V}\right)
$$

where:

$$
\begin{aligned}
& \rho=\text { density of air }\left(\mathrm{lb} / \mathrm{ft}^{3}\right) \\
& \mathrm{C}_{\mathrm{p}}=\text { specific heat of air }\left(\mathrm{Btu} / \mathrm{lb}{ }^{\circ} \mathrm{F}\right) \\
& V=\text { volume of home }\left(\mathrm{ft}^{3}\right)
\end{aligned}
$$

This is expected to be a reasonable assumption given the extreme tightness of the homes tested and the nature of the cracks through which infiltration was observed using infrared imaging. In cases when it was not possible to obtain an accurate infiltration measurement using the tracer gas technique, the infiltration load could sometimes be inferred by observing the change in overall measured UA from another case, where the only difference in heat loss was expected to be infiltration.

\subsection{Furnace Efficiency Tests}

The overall efficiency of the furnace for each home was measured in the following manner: the rate at which natural gas was drawn by the furnace when running was measured using the building gas utility meter and a stopwatch. We assumed that this rate was a constant whenever the furnace gas valve was on. The furnace was then run in a normal manner using its own thermostat, and the length of time the gas valve was on was recorded over the test period. The amount of energy used per degree temperature difference between inside and outside the home (equivalent in units to a UA value) was then calculated:

$$
\mathrm{UA}_{\text {fum }}=\mathrm{rtC} / \Delta \mathrm{T}
$$


where:

$$
\begin{aligned}
& r=\text { gas use rate }\left(\mathrm{ft}^{3} / \mathrm{hr}\right) \\
& \mathrm{t}=\text { total gas valve on time of furnace }(\mathrm{hr}) \\
& \mathrm{C}=\text { energy content of gas }\left(\mathrm{Btu} / \mathrm{ft}^{3}\right) \\
& \Delta \mathrm{T}=\text { average temperature difference between inside and outside }\left({ }^{\circ} \mathrm{F}\right)
\end{aligned}
$$

The furnace efficiency was then calculated as:

$$
\eta=\mathrm{UA}_{\text {coheat }} / \mathrm{UA}_{\text {furn }}
$$

where:

$$
\mathrm{UA}_{\text {coheat }}=\text { overall UA measured during electric coheat test }\left(\mathrm{Btu} / \mathrm{hr}{ }^{\circ} \mathrm{F}\right)
$$

(This electric coheat test must be done under conditions as similar as possible to those under which the furnace test is conducted. For example, if we wish to determine the change in furnace efficiency caused by holes in the rodent barrier, four tests must be done at the same temperature difference: an electric coheat test with no holes, a gas furnace test with no holes, an electric coheat test with holes, and a gas furnace test with holes. The change in efficiency would then be taken as:

$$
\begin{aligned}
\Delta \eta_{\text {furn }} & =\left(\eta_{\text {furn,no holes }}-\eta_{\text {furn,holes }}\right) \\
& =U A_{\text {coheat,no holes }} / \mathrm{UA}_{\text {furn,no holes }}-\mathrm{UA}_{\text {coheat,holes }} / \mathrm{UA}_{\text {furn,holes }}
\end{aligned}
$$

\subsection{Air Tightness}

The tightness of the homes under various conditions was measured using blower-door depressurization tests. Equivalent leakage areas (ELAs), were calculated from the blower-door data using established techniques (11). Once the ELA was determined, infiltration rates under average natural outdoor Colorado conditions of temperature and wind were estimated using a computer program written at NREL (12) based on a mathematical model $(13,14)$. 


\subsection{Results}

The proposed standard and the draft HUD calculation manual do not include infiltration losses in the heatloss coefficient calculations. For this reason the measured heat loss had to be separated into a conduction portion and an infiltration portion so that an "apples to apples" comparison could be made between the measurements, the standard, and the calculations. This was done by performing a tracer gas decay test (11) to measure the infiltration rate. The heat loss caused by this infiltration was subtracted from the measured overall UA value of the home to obtain $\mathrm{UA}_{\mathrm{c}}$.

\subsection{Compliance With Proposed Standard}

According to the new proposed standard, the following values of $U_{o, c}$ are specified:

$$
\begin{aligned}
& \text { (cold zone) } \mathrm{U}_{\mathrm{o}, \mathrm{c}}=0.079 \mathrm{Btu} / \mathrm{hr} \mathrm{ft}^{2 \circ} \mathrm{F} \\
& \text { (warm zone) } \mathrm{U}_{\mathrm{o}, \mathrm{c}}=0.109 \mathrm{Btu} / \mathrm{hr} \mathrm{ft}^{2{ }^{\circ} \mathrm{F}}
\end{aligned}
$$

We tested the homes under both a still-air and a repeatable-wind condition. The pressure field created in an outside free-stream wind cannot be replicated exactly within the confines of the environmental enclosure. However, spot pressure measurements, tracer gas tests, and coheating tests, performed with and without the wind emulator, indicate that the fans create conditions approximating those associated with a 3-mile-per-hour free-stream wind $(4,6)$. The measurements taken under the emulated wind condition most closely match the assumptions built into the standard and the compliance calculation method. We determined this by calculating an area-weighted average of the wind speeds associated with the exterior surface coefficients specified in the compliance manual as shown in Table 1.

Table 1: Exterior Film Resistances Specified in HUD Compliance Manual

\begin{tabular}{cccc}
\hline Component & $\begin{array}{c}\text { Exterior Film } \\
\text { Resistance }\end{array}$ & Component Area & $\begin{array}{c}\text { Associated } \\
\text { Wind Speed }\end{array}$ \\
\hline Wall & .25 & $1216 \mathrm{ft}^{2}$ & $7.5 \mathrm{mph}$ \\
Ceiling & .61 & $960 \mathrm{ft}^{2}$ & $0 \mathrm{mph}$ \\
Floor & .92 & $960 \mathrm{ft}^{2}$ & $0 \mathrm{mph}$ \\
\hline
\end{tabular}

*(Reference 2, figures 4.4, 4.6 and 4.10)

The area-weighted average windspeed can be calculated from this information as $2.9 \mathrm{mph}$, which is very close to the approximate 3-mph wind produced by the emulator.

Figure 2 shows the standard target value, the value calculated using the draft HUD compliance calculation method, and the measured results under both still-air and wind conditions. Two other bars are seen on the right of Figure 2. These bars show results from previous tests of older homes before and after retrofit with an NREL-recommended weatherization package (6). These results are shown for comparison to the new homes. 
$U_{0, c}$ (Ubverall, conduction)

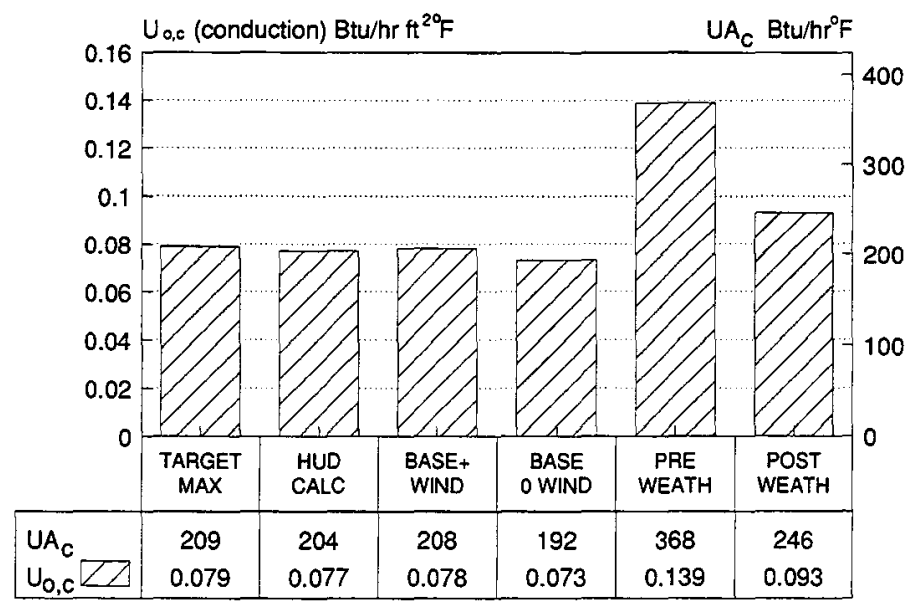

Base+Wind passed by $1 \%$, Base by $8 \%$

Schult window area $=82 \mathrm{ft}^{2}$

Weath avg window area $=115 \mathrm{ft}^{2}$

2a. Cold-Zone Home

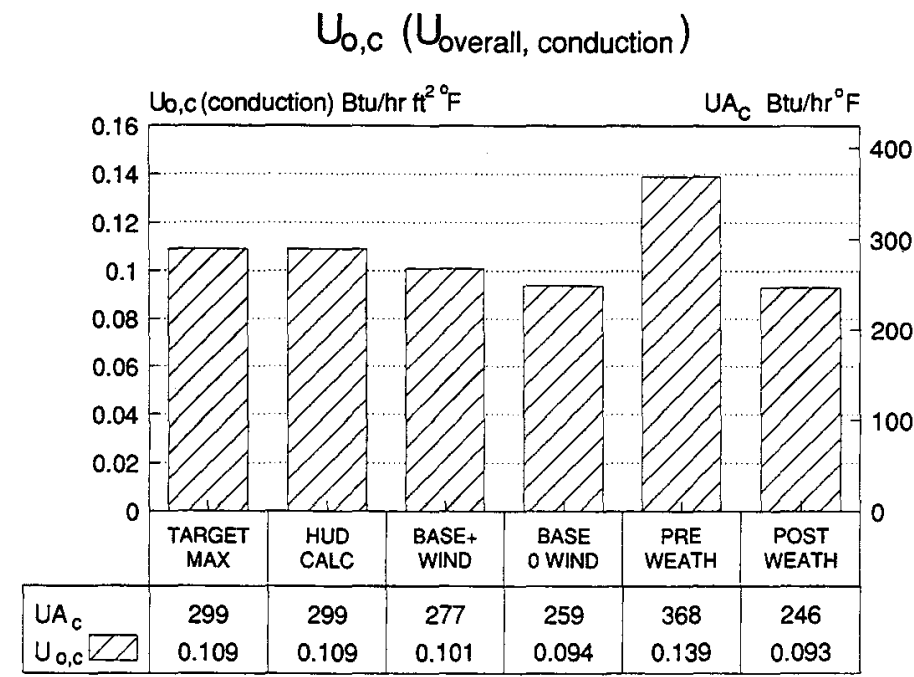

Base+Wind passed by $7 \%$, Base by $14 \%$

Schult window area $=82 \mathrm{t}^{2}$

Weath avg window area $=115 \mathrm{t}^{2}$

2b. Warm-Zone Home

Figure 2. Comparison of measured-to-calculated overall heat loss coefficients for both homes. "Base" refers to the base case: a home in as-new condition with no wind impinging on it. "Target Max" refers to the proposed standard for heat loss coefficients. 
The cold-zone and the warm-zone homes met the proposed standard, with the cold-zone home coming in about $1 \%$ below the maximum allowable value of $U_{o, c}$, and the warm-zone home passing by about $7 \%$. Figure 2 shows that the wind causes an increase in the measured value of $\mathrm{U}_{\mathrm{o}, \mathrm{c}}$, as is expected. Even with the wind, however, the homes met the standard. The compliance calculation method yielded predictions that were also quite close to the measured values (with wind).

The homes met the proposed standard with minimal design changes required by the manufacturer. In the warm-zone home, roof, floor, and wall sections were all typical for this manufacturer, as were the window and door components. In the cold-zone home all components were typical except for the wall, which was increased from 2-in.-by-4-in. to 2-in.-by-6-in. stud-wall construction to accommodate a thicker insulation batt. Even the 2-in.-by-6-in. wall is an option already offered by the manufacturer (at additional cost to the consumer). The only changes from the usual design were the amounts of insulation specified in the floor and roof. These increased insulation thicknesses were able to fit into the typical cavity depth available in the designs normally used by this manufacturer. Table 2 shows the major as-built thermal characteristics of the test homes.

Table 2. Thermal Characteristics of Test Homes

\begin{tabular}{|c|c|c|}
\hline Component & Cold-Zone Home & Warm-Zone Home \\
\hline Floor Wings & $\begin{array}{l}R 20 \text { ( } 23.5^{\prime \prime} \text { batts compressed in a } \\
2 \times 6 \text { joist cavity) }\end{array}$ & R11 (1 3.5" batt) \\
\hline Floor Pan & R26 (1 3.5" blanket doubled over) & R11 (blanket) \\
\hline Floor Average & $\mathbf{R} 23$ & R15 \\
\hline Ceiling: Vaulted & R17 & $\mathrm{R} 17$ \\
\hline Ceiling: Flat & $\mathbf{R} 26$ & R26 \\
\hline Ceiling Average & R18 & R18 \\
\hline Walls & R14 (2" X 6" framing, 16" o.c.) & R10 (2" X 4" framing, $16 "$ o.c.) \\
\hline Windows & $\begin{array}{l}\text { R1.4 (1 pane + interior self storing } \\
\text { storm) }\end{array}$ & R0.8 (1 pane) \\
\hline Heating Duct & R4 board inside $R 22$ blanket & R4 board inside R11 blanket \\
\hline Furnace & Gas-forced air & Gas-forced air \\
\hline Return Air & Through living space & Through living space \\
\hline $\begin{array}{l}\text { Internal Dimensions } \\
\text { Length X Width }\end{array}$ & $55.35^{\prime}$ X 14.7' & $55.7^{\prime} \times 15^{\prime}$ \\
\hline Wall Height & 7 & $7.5^{\prime}$ \\
\hline Vaulted Ceiling Area & $636 \mathrm{ft}^{2}$ & $653 \mathrm{ft}^{2}$ \\
\hline Flat Ceiling Area & $178 \mathrm{ft}^{2}$ & $183 \mathrm{ft}^{2}$ \\
\hline Window Area & $82 \mathrm{ft}^{2}$ & $82 \mathrm{ft}^{2}$ \\
\hline Floor Area & $814 \mathrm{ft}^{2}$ & $836 \mathrm{ft}^{2}$ \\
\hline Volume & $6173 \mathrm{ft}^{3}$ & $6580 \mathrm{ft}^{3}$ \\
\hline
\end{tabular}


Although these results appear to be encouraging, the homes tested were built with the manufacturer's "minimum window" option, $82 \mathrm{ft}^{2}$. Manufactured homes of this size typically have a window area of about $115 \mathrm{ft}^{2}(3)$. If all other components of the homes were kept the same, but the window area were increased to $115 \mathrm{ft}^{2}, \mathrm{U}_{\mathrm{o}, \mathrm{c}}$ for the cold- and warm-zone homes would increase to about .084 and $.122 \mathrm{Btu}^{2} \mathrm{hr} \mathrm{ft}^{2} \mathrm{~F}$ respectively, as estimated by using standard American Society of Heating, Refrigeration, and Air Conditioning Engineers (ASHRAE) heat-loss calculation methods. Thus the homes would no longer meet the proposed standard target values. Some structural or component design changes would be necessary to meet the standard with the larger glass areas. Several of the many ways the homes could be brought back into compliance are listed below:

Warm-Zone Home with $115 \mathrm{ft}^{2}$ of Window

- Add self-storing storm windows

- Increase from R11 in the floor pan and wings to R22 and R19 respectively, and change the wall thickness to 2 in. by 6 in. to accommodate increasing the wall insulation from R11 to R19.

Cold-Zone Home with $115 \mathrm{ft}^{2}$ of Window

- Increase the average roof insulation from R16 to R26 by substituting the flat-roof-truss construction for the vaulted roof scissor-truss construction

- Increase the average roof insulation from R16 to R26 by redesigning the scissor truss to be deeper in the heel and deeper overall (this would also require redesigning the flat-roof truss to match the pitch of the scissor truss).

Schult typically uses wood siding and triangular truss roofs with blown-in insulation for both their single and double-wide models. Roughly half of the manufactured housing industry is now single-wide units, and eighty percent of these still use metal siding and bow-string truss galvanized roofs. This will probably make it harder for them to meet the new standard.

\subsection{Sensitivity of Thermal Performance}

\subsubsection{Heat Transmission Coefficient}

Several tests were conducted on both homes to determine their sensitivities to various situations that may be encountered under normal use of the homes. The parameters tested are listed in Table 3.

Rips in the rodent barrier were made in such a way as to simulate the types of holes that are likely to occur under routine maintenance of the home, and that occur because of normal field hook-ups of gas, water, electrical, and waste lines. Cuts were made and insulation shifted to the side at strategic places such as under the toilets, as if repairs had been made to those parts of the home.

For some tests, the furnace fan was hard-wired on, without the furnace actually producing any heat. This was to characterize the effects of pressure gradients being induced by the forced-air circulation system. 
Table 3. Parameters Tested in Sensitivity Study

\begin{tabular}{lll}
\hline \multicolumn{1}{c}{ Parameter } & \multicolumn{1}{c}{ Expected Effect on UA } & \multicolumn{1}{c}{ Reason } \\
\hline Wind & $\begin{array}{l}\text { increased infiltration } \\
\text { and conduction loss } \\
\text { increased infiltration, duct, and } \\
\text { conduction losses }\end{array}$ & $\begin{array}{l}\text { induced pressure gradients and } \\
\text { increased exterior film coefficient } \\
\text { allows infiltration through belly, } \\
\text { escape of duct losses, and } \\
\text { bypassing of floor insulation }\end{array}$ \\
& $\begin{array}{l}\text { increased infiltration and duct } \\
\text { loss }\end{array}$ & $\begin{array}{l}\text { higher pressure in ducts and in } \\
\text { belly }\end{array}$ \\
Furnace fan on & increased infiltration and duct \\
loss & $\begin{array}{l}\text { greater pressure gradients between } \\
\text { rooms and outside, and between } \\
\text { ducts and outside }\end{array}$ \\
\hline
\end{tabular}

Figure 3 shows that, in general, the effects expected in Table 3 were observed. Both homes were fairly resistant to degradation in performance from wind, rips in the rodent barrier, and operation of the furnace blower. This indicates that the ducts and floor were relatively tight, and the under-floor cavities were sufficiently packed with insulation to suppress air bypasses. However, when the interior doors were shut with the furnace blower operating, the heat losses for the cold- and warm-zone homes increased by 39 and $36 \mathrm{Btu} / \mathrm{hr}{ }^{\circ} \mathrm{F}$ respectively. In this case, the overall heat-loss coefficient exceeds the standard for both homes. This is important because it is likely that occupants will close bedroom doors, especially at night (the coldest portion of the day) when the furnace will also be operating the most.

This effect can be explained by the design of the forced-air heating system. Air is delivered to the individual rooms via air ducts under the floor (in the belly). The air then returns to the furnace through an air intake at the furnace itself, positioned in the central kitchen/living room/dining room area. When all the interior doors are open, the return air can pass freely through the doorways to the furnace. If the interior doors are closed, the air must pass through relatively small cracks under the doorways to return to the furnace. This results in higher pressures in the delivery ducts and end rooms, which are partially sealed off from the central room by the doors, and lower pressures in the central room. The effect of these relatively large pressure gradients is to increase the overall infiltration rate of the home and ducts, thus increasing the overall heat-loss coefficient.

\subsubsection{Furnace Efficiency}

Figure 4 shows the measured combined furnace and duct efficiencies for both homes under some of the same variety of conditions as described in the previous section on thermal sensitivities. In general, the heating system efficiencies are higher in the cold-zone home. This is probably because the cold-zone floor cavity contains R22 insulation under the heating duct, whereas the warm-zone home contains R11. The largest effect from the parametric changes in both homes is again from the combination of closed interior doors and operation of the furnace blower. In the cold- and warm-zone homes this caused a decrease in heating system efficiency from the base case (or the "base + wind" case) of 5\% and 9\% respectively. The greater decrease in furnace and duct efficiency for the warm-zone home may also be caused by the smaller amount of floor insulation in that home. In both homes, the efficiency decreases when holes are cut in the rodent barrier and when the interior doors are closed. The approximate 3-mph wind, however, does not appear to have any effect on the delivered heat efficiency of either home, indicating that the combination 
THERMAL ROBUSTNESS

CONDUCTION AND INFILTRATION

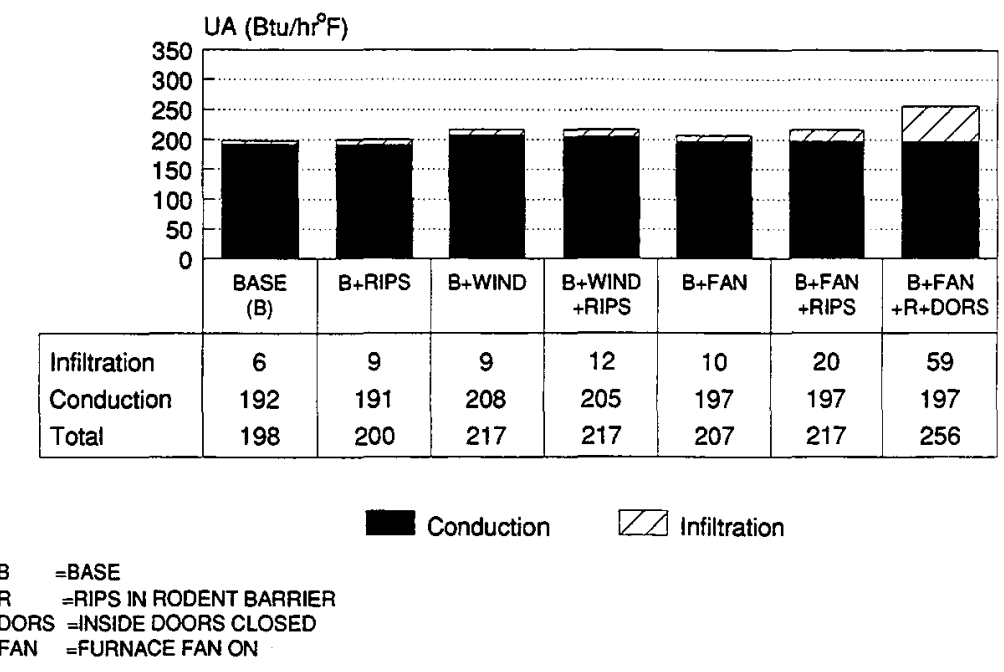

3a. Cold-Zone Home

THERMAL ROBUSTNESS

CONDUCTION AND INFILTRATION
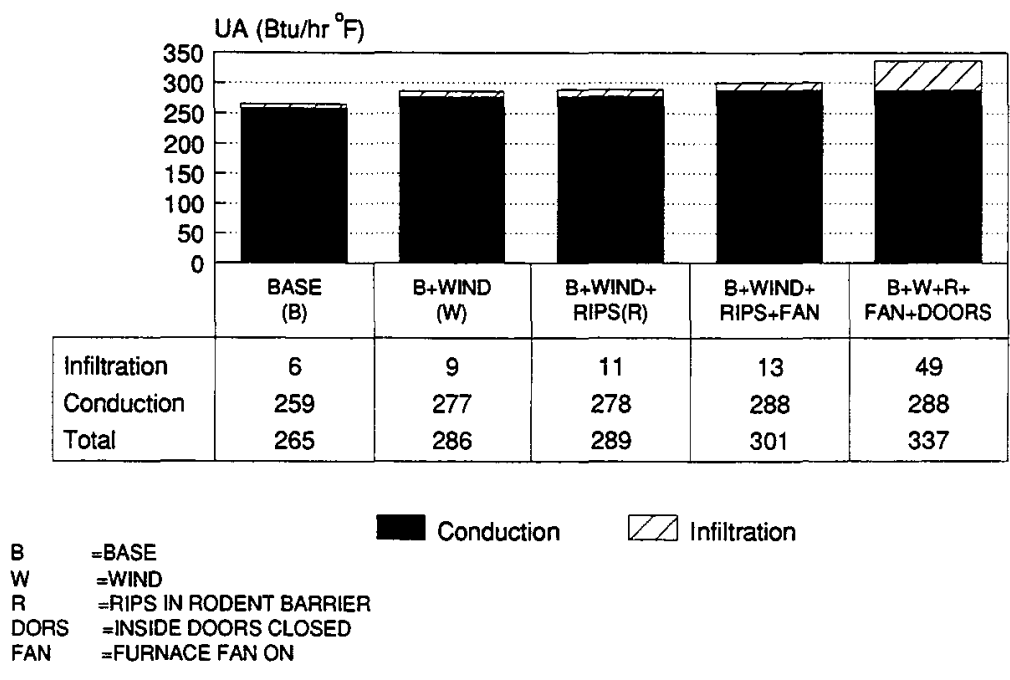

3b. Warm-Zone Home

Figure 3. Results of varying several parameters that affect thermal performance of manufactured homes. Base case refers to as-new condition, no wind. 


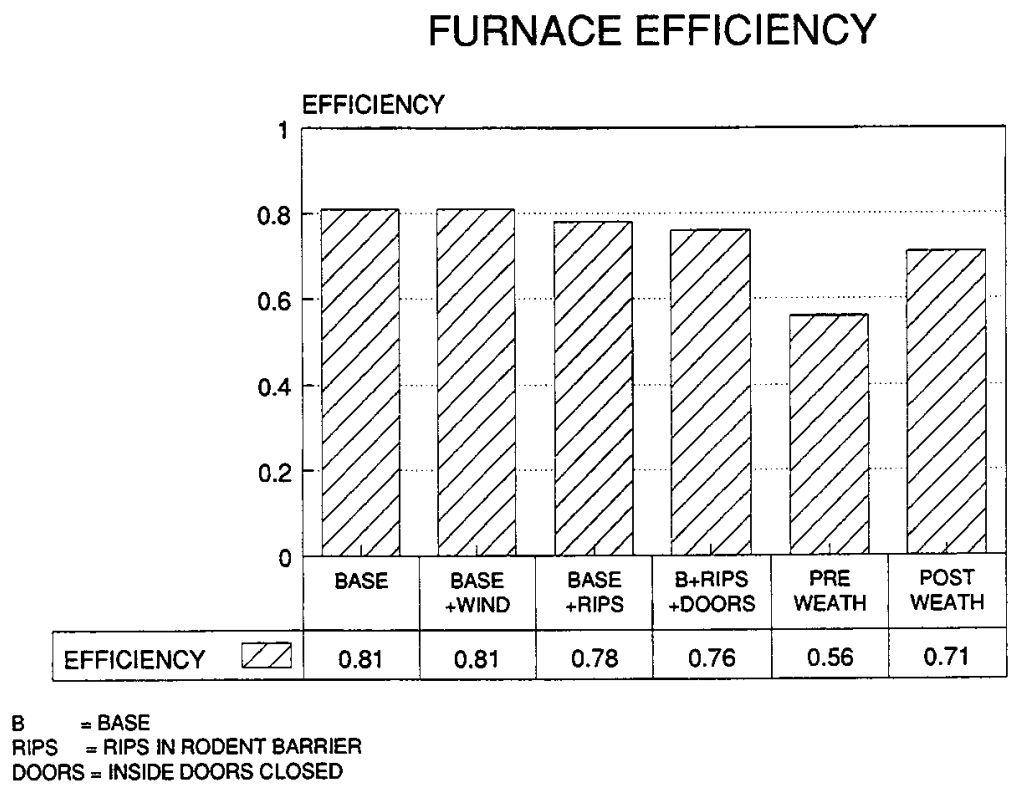

4a. Cold-Zone Home

\section{FURNACE EFFICIENCY}

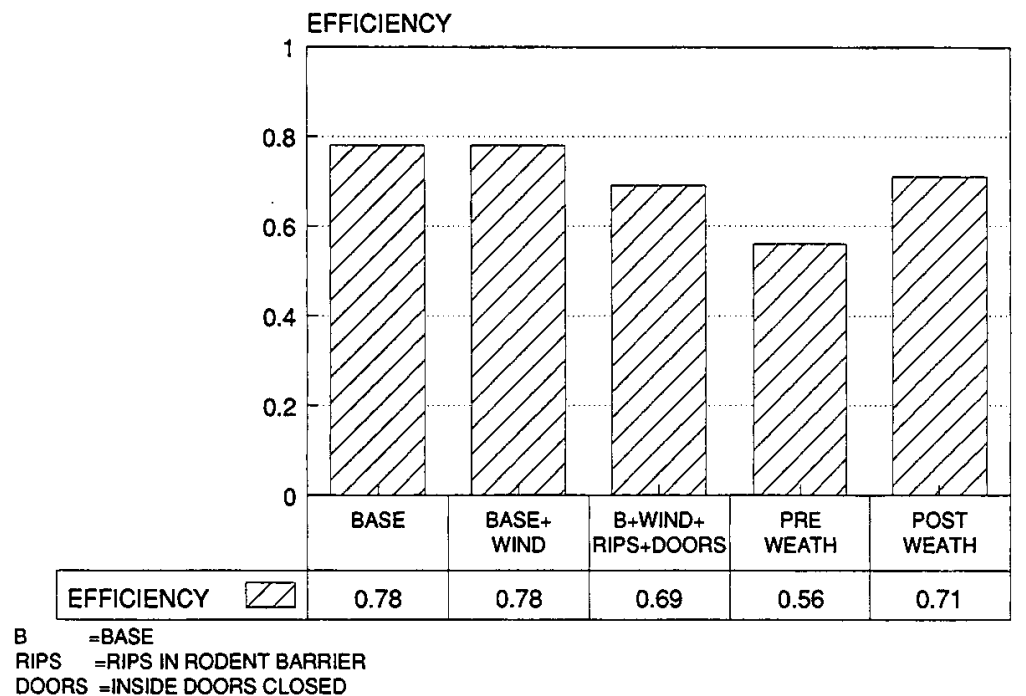

4b. Warm-Zone Home

Figure 4. Effects on furnace efficiency of varying several parameters that affect thermal performance of manufactured homes. Base case refers to as-new condition, no wind. 
of an intact rodent barrier and either R22 or R11 under the duct, render the homes relatively impervious to duct heat loss from wind-induced lateral pressure gradients at this wind speed. It is possible that decreases in efficiency could be detected under greater wind speeds.

The bars labelled "pre weath" and "post weath" in Figure 4 represent the average heating system efficiencies before and after weatherization for eight older homes tested in a previous weatherization project (6). These data can be compared to the bars labelled "base" case for the new homes.

\subsubsection{Air Tightness}

Air tightness of each of the two homes was measured under various conditions, as shown in Figure 5. The cold-zone home was tested before it left the Schult factory in Plainville, Kansas, and again when it arrived in Denver (about a 300-mile trip). The intention was to see if the home became less tight because of the stresses encountered on a highway trip from the factory. One can see from Figure 5 that the home appeared to become slightly tighter after transport with a leakage area reduction of about $5 \mathrm{in}^{2}$. Blower door measurements are generally accurate to within about + or $-5 \%$. This indicates that the leakage areas did not increase from over-the-road transport. The slight tightening may be experimental uncertainty, or may be because the home was not levelled and blocked at the factory, whereas it was at the CMFERT facility. Windows and doors may be sealed better once leveling squared up framed openings.

As expected, both homes showed an increase in ELA and infiltration rate after holes were cut in the rodent barrier. In the warm-zone home, we also sealed off the furnace ducts to observe any change in ELA. We measured only a 3 -in ${ }^{2}$ reduction in ELA-CAN (Canadian equivalent leakage area). Visual observations revealed approximately a 6 -in ${ }^{2}$ gap between the furnace plenum and supply duct. This indicated that the furnace ducts were relatively tight by comparison to many older units we have tested in the Weatherization Program and did not contribute much to the overall infiltration rate of the homes. Although this is encouraging, one should remember that the ducts were new. Weatherization personnel have reported that the tapes used to seal the fiberglass folding board duct sections degrade over time, and that these kind of ducts are extremely difficult to repair (15). Also, even small supply duct leaks can contribute to relatively large heat losses from pressure imbalances as was observed previously with the closing of interior doors while the furnace blower operated.

We also blower-door tested three other homes that happened to be completed at the factory while we were on site (Figure 5a, last three pairs of bars). This was done to begin assembling a data base on the airtightness for typical new manufactured buildings. All the homes were extremely tight-perhaps too tight. ASHRAE recommends an average infiltration rate of at least 15 cubic feet per minute (cfm) per person. The blower-door results for these homes in their original condition from the factory averaged $10 \mathrm{cfm}$ per person. It may be that some sort of mechanical ventilation system should be required, or that the new standard should include maximum and minimum fresh air requirements. This is especially important for those individuals who are sensitive to the gases emitted from the materials in these types of homes.

\subsubsection{FSEC Tests}

Some additional air-tightness tests were conducted by the Florida Solar Energy Center (FSEC) using techniques that they have been developing for field diagnostics (16). These techniques include a "Duct Blaster" or blower designed to allow direct measurement of leakage areas in ducts, a Shortridge flowhood designed to directly measure duct register airflow, and several differential pressure sensors. Some results from these tests are shown in Tables 4 and 5. 


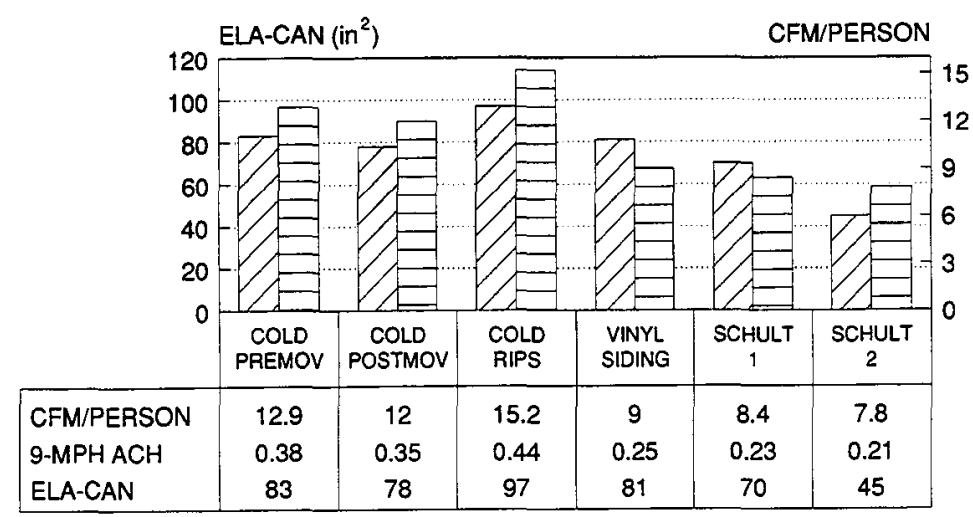

$\square \triangle$ ELA-CAN $\rightleftharpoons$ CFM/PERSON

PREMOV = BEFORE LEAVING FACTORY

POSTMOV = AFTER TRANSPORT

RIPS $=$ RIPS IN RODENT BARRIER

5a. Cold-Zone Home and Others

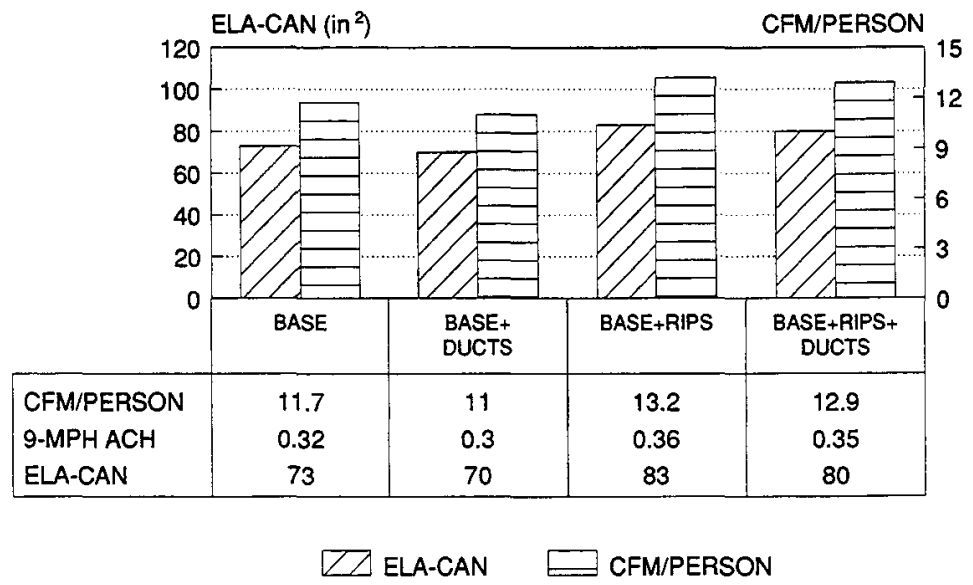

DUCTS $=$ HEATING DUCTS SEALED OFF

RIPS = RIPS IN RODENT BARRIER

5b. Warm-Zone Home

Figure 5. Results of blower-door tests on several new Schult homes. Note that all predictions of natural infiltration levels are below the ASHRAE recommendation of $15 \mathrm{cfm} /$ person. Base refers to as-new condition. 
Table 4. FSEC "Duct Blaster" Results

\begin{tabular}{lcccc}
\hline & $\begin{array}{c}\text { 0 Holes in rodent } \\
\text { barrier }\end{array}$ & $\begin{array}{c}\text { 3 Holes in rodent } \\
\text { barrier }\end{array}$ & CFM & \% Difference \\
\hline ELA (4pa) & $9.3 \mathrm{in}^{2}$ & $9.4 \mathrm{in}^{2}$ & $33 / 33$ & 1 \\
EqLA (10pa) & $15.7 \mathrm{in}^{2}$ & $16.1 \mathrm{in}^{2}$ & $53 / 55$ & 3 \\
FLA (50pa) & $16.4 \mathrm{in}^{2}$ & $17.4 \mathrm{in}^{2}$ & $126 / 134$ & 6 \\
\hline
\end{tabular}

Table 5: Pressure Difference Inside to Outdoors

\begin{tabular}{lc}
\hline \multicolumn{1}{c}{ Experimental Condition } & Pressure Difference (pa) \\
\hline Furnace fan off & -0.2 \\
Furnace fan on & -1.2 \\
Furnace fan on, all interior doors closed & -4.0 \\
Furnace fan on, master bedroom door closed, & -3.6 \\
all other interior doors open & \\
\hline
\end{tabular}

The FSEC test results were generally consistent with those from NREL indicating:

- $\quad$ "Duct leakage is small" (16)

- "Very little change in duct leakage after the rodent barrier was cut" (16)

- Pressure imbalances of approximately 4 pascals between the dining room/kitchen area and the outside of the home with interior doors closed and the furnace blower operating (16).

These tests were more sensitive for measuring small duct leaks than the subtractive whole-house blowerdoor method currently used by energy auditors. 


\subsection{Infrared Thermography}

We scanned the interior and exterior surfaces of the cold- and warm-zone homes using an Inframetrics Model 600 Infrared Imaging System to investigate potential thermal anomalies in the construction details. This equipment can discriminate temperature differences as small as $0.1^{\circ} \mathrm{F}$. The system produces a color coded visual image of the surface temperatures within its field of view. Thus anomalies, which would otherwise be invisible, such as thermal shorts, thermal bypasses, compressed or missing insulation, convective loops, and air leakage cracks, can be detected given a sufficient temperature difference between the inside and outside of the home. FSEC also scanned the homes with infrared equipment more typical of that which can conveniently be used in the field.

Although both FSEC and NREL found a number of apparent thermal anomolies, our co-heating tracer-gas, and blower-door tests indicated that only one of these, the connection of the furnace to the heating duct via the floor plenum, was of major thermal significance in these two homes. A list of our specific observations follows:

- Air leakage was observed where pipe penetrations occurred, such as near the water heater closet, under bathtubs, and under kitchen and bathroom cabinets.

- Air leakage was observed above the circuit breaker panel box where electric wires penetrate into the ventilated attic.

- Air leakage was observed at several points along the top and bottom plates, and at the angled construction joints of the bay windows.

- The ducts were relatively tight; however, a sizeable leak was observed where the vertical furnace plenum feeds into the horizontal heat supply duct. This showed up as a hot spot on the utility room wall and floor where a gap had been left in the insulation for the dryer vent. This probably partially accounts for the increase in building loss coefficient and decrease in delivered heat efficiency observed when interior doors were closed with the furnace blower operating. This gap was visually observed during the construction of the homes, and was estimated to be about 6 in $^{2}$ in the warm-zone home, and $12 \mathrm{in}^{2}$ in the cold-zone home.

- The scissor trusses used in the vaulted portion of the ceiling were clearly visible from the inside, indicating some degree of thermal shorting. This was expected because these trusses are very thin with little room for the insulation. The triangular roof trusses used for the flat portion of the ceiling were much deeper and did not show this problem except at the outer edges where the truss heels are quite narrow.

- A small difference in interior floor surface temperature was observed between floor area over the "wings," and floor area over the "pan" when the homes were heated with their own furnace and duct systems (as opposed to co-heating in which the homes are heated by electric resistance heaters in the living space). This was because the insulation was detailed differently in the wings then in the pan, and because the pan contained the heating ducts. The wings contain batts of insulation in the floor joist cavities while the pan contains a fiberglass blanket looped under the heating duct.

It would have been very difficult for us to interpret the significance of the infrared-based observations had we not had the ability to directly measure infiltration, building heat-loss coefficient, and delivered heat efficiency. Also, the factory observations of the construction of these homes were extremely helpful for 
interpreting the infrared images. For example, even though we observed air leakage, the homes were quite tight as determined by blower-door and tracer-gas tests. Thus in these homes, which do not have mechanical ventilation, the leakage area is already somewhat less than that needed to provide adequate fresh air (according to the latest ASHRAE recommendations(17)). Even though we observed thermal bridging in a number of places, we know that the overall effect was not great because the measured heat transmission of the homes was low enough to meet the proposed HUD standard, and fell within $8 \%$ of calculations in which no thermal anomalies were assumed.

The ability to conduct the infrared scans under steady-state conditions also proved extremely informative, and could eventually lead to improved interpretation of infrared images taken under field conditions. In this process we learned much about the homes, and much about some of the potential problems with infrared thermography. This is illustrated by differences observed between sets of scans taken under both steady-state and non-steady-state conditions. Under non-steady-state conditions a $10^{\circ} \mathrm{F}$ difference in temperature between the interior surface of the portion of the floor over the pan, and the portion of the floor over the wings was observed. This indicated that a large thermal anomaly, such as poorly installed insulation in the wings, existed. Under steady-state conditions less than a $1^{\circ} \mathrm{F}$ temperature difference between these areas was measured. This, along with our observation of the construction of the homes supported the conclusion that the cause was the slightly different detailing of the insulation in the pan and in the wings, and the proximity of the heating duct to the pan. The difference in results was because the non-steady measurements were performed about 6 hours after the home was heated from $50^{\circ} \mathrm{F}$ to $80^{\circ} \mathrm{F}$. The wings did not heat up as fast as the pan because the heating duct runs through the pan above the insulation. Consequently, the floor surface above the wings was colder than the floor surface above the pan, and the rodent barrier below the pan was warmer than the rodent barrier below the wings.

Many structural elements appeared to have servere thermal shorts when observed from the inside because of the temperature history of the units. This was because of their thermal capacitance. When the home was rapidly heated, these structures remained cold longer than the insulation cavities and interior finishes, thus giving the appearance of thermal bridging. Once the homes reached steady state, many of these temperature differences became much less pronounced. Finally, we observed that the rodent barrier material was slightly reflective in the infrared spectrum. Therefore in some cases heat reflections from the body of the cameraman appeared to indicate large heat leaks in the belly cavity.

Methodological problems of this nature were easy to find because of the opportunity to do some of the measurements under controlled and repeatable conditions. The NREL controlled environment can potentially provide the opportunity to improve many commonly used field diagnostic techniques. 


\subsection{Factory Observations}

One of the most interesting aspects of this project was the one-week factory visit to observe the construction of the test homes. This afforded the project scientists the additional opportunity to become familiar with normal factory operations, production-line procedures, and quality control methods. The following is a list of observations and suggestions from the site visit. These suggestions are not intended to supersede the knowledge or experience of the production managers and engineers.

- The floor joist spacing was not always consistent. Most joists were 16 in. on center (oc), but some were $18 \mathrm{in}$. oc. The insulation batts were precut for the 16-in. spacing, which caused insulation gaps to be left in the floor wings, or the production line to be slowed down while insulation scraps were hand cut to fill the gaps. Modular design to a 16 in. structural floor module would eliminate odd joist spacing simplifying the installation of insulation batts. This would also allow the design of the chassis wing supports to be more standardized, and allow elimination of the band (rim) joist marking station.

- The plastic strapping that supports the insulation batts between the floor joists was not stapled at each joist. This allowed the batts to sag leaving voids behind the band joist and creating a thermal short at the floor edge. This problem was especially evident in the warm-zone home where the batts were only R11 (3.5 in.). Stapling the strapping at every joist would help. A better solution would be to always fill the joist cavity with a full-depth batt (R19 for these homes) and staple at every joist regardless of the zone for which the home was designed.

- The stud spacing in the 2-in.-by-6-in. wall was 16 in. oc. Two-in.-by-six-in. studs are structurally sufficient for $24 \mathrm{in.} \mathrm{oc} \mathrm{spacing.} \mathrm{Not} \mathrm{only} \mathrm{would} \mathrm{material} \mathrm{be} \mathrm{saved,} \mathrm{but} \mathrm{the} \mathrm{average} \mathrm{resistance} \mathrm{of}$ the wall would improve because of the decreased framing area. Another alternative would be to use a standard $2 \times 4$ wall 16 in. oc with rigid board insulation on the outside for the R19 wall.

- The rolls of rodent barrier material were not wide enough for the 16 -foot-wide homes. Wider stock would eliminate the need for a hand-fabricated glue joint and reduce material waste. The availability of wider rodent barrier roll stock should be investigated.

- A flange detail should be developed to seal all rodent barrier penetrations.

- A flange detail should be developed to seal the connection between the furnace plenum and the heating duct where gaps were observed in both homes.

- A template or other quality control procedure should be instituted to ensure that the rough opening for the furnace plenum is properly aligned with the top of the heating duct. Otherwise a duct leak is unavoidable.

- The fiberglass folding-board ducts look flimsy and are difficult to repair, and the durability of the tape joints is questionable. Additionally it is difficult to design good durable connections between the floor register sleeves and the heating duct. Alternative heating duct materials and connection systems should be investigated.

- The scissor trusses are quite narrow, and extremely narrow at the heels. Also, the double top chord toward the peak of the truss further limits the depth of ceiling insulation in the ventilated roof design used with these homes. A deeper truss design would solve these problems. An alternative would be to eliminate the ventilated roof design so that the attic could be completely filled with 
insulation. However, this would need study to determine if this might cause long-term moisture condensation problems in the attic in humid climates.

- Rigid insulation should be used under the soil line support where it crushes the blanket insulation. Duct material scraps could be used for this.

- The use of "truss-studs," as is common in Swedish manufactured housing, should be considered. These use less material, simplify wiring and plumbing, and allow for higher average insulation levels by reducing thermal shorts from framing. 


\subsection{Conclusions}

On the whole, both the warm-zone home and the cold-zone home performed quite well. A flaw observed in both homes was the gap between the furnace plenum and supply duct. Both homes met the proposed standard under normal coheating conditions.

We found, however, that the thermal performance of the homes dropped appreciably when the interior doors were closed and the furnace fan was operating. This will not be an unusual occurrence when the house is occupied, and the homes failed to meet the proposed standard under these conditions. This was partially caused by the gap between the furnace plenum and supply duct.

The homes were found to be extremely tight, so tight in fact that they both fell below the minimum value of $\mathrm{cfm}$ per person recommended by ASHRAE. This may need to be addressed in terms of indoor air quality, especially in view of the types of materials typically used in the construction of manufactured homes.

Schult selected their minimal-window-area $\left(82 \mathrm{ft}^{2}\right)$ model for the tests. Had the window area been more typical (about $115 \mathrm{ft}^{2}$ ), substantive design changes would have been necessary to meet the standard. Several design alternatives were analyzed to bring units having larger window area into compliance with the standard.

Improvements could be made to the procedures for installing floor insulation at very low cost. Although this is not necessary to meet the standard, it would improve comfort and long-term resistance to degradation in thermal performance.

The new HUD compliance calculation method was quite accurate for these particular homes, which do not contain construction details that exacerbate convective by-pass heat loss. The method may not work as well for homes still using ventilated walls, mostly empty interstitial cavities, and cavities with excessive crack area to the outside. Also, the method does not account for natural infiltration, duct leakage, or heat losses from operation of forced-air system blowers. 


\subsection{Recommendations}

a) A major loophole in the proposed standard as currently worded is the definition of $U_{o}$ (equation 1). This value is normalized by the total surface area of the home. This allows a designer, when necessary, to meet the letter (but not the spirit) of the current and proposed standard by increasing the height of the walls. This increases the ratio of low heat-loss surface area to that of high heat-loss components such as windows. Thus, $U_{o}$ is decreased, but the total heat-loss of the building is actually increased. No one benefits: the manufacturer incurs greater materials costs, the building uses more energy, and the consumer pays higher fuel bills.

This method of increasing the wall area to decrease the $U_{0}$ was used on the warm-zone home when it failed to meet the proposed standard with its usual $84^{\prime \prime}$ wall. Schult design engineers merely specified an increase in the wall height to $90^{\prime \prime}$, and so were able to meet the standard. The Schult engineers reported to us that this was frequently done by many manufacturers. This problem can be simply rectified by basing $U_{0}$ on floor area instead of surface area.

b) Maximum and minimum air leakage criteria should be included as part of the standard. Blower doors could make determination of the leakage quite simple for both manufacturers and compliance inspectors. A simple protocol could be developed for this (Schult was very interested in the blower door as an in-house quality control tool when we demonstrated its use to them).

c) A guideline should be included in the new standard for duct integrity, as this is a potentially large source of heat loss. A simple test protocol could be developed for this.

d) A requirement for balancing air distribution, retum air systems, and forced ventilation systems should be included in the standard. Cost-effective design guidelines could be determined experimentally in the environmental enclosure.

e) The above recommendations should be incorporated into the new manufactured home construction and safety standards (MHCSS).

f) A project should be initiated to assist "low-end" manufacturers in meeting the standard.

g) A project should be initiated to develop an in-factory compliance test (analogous to an Environmental Protection Agency mileage test) for use by HUD inspectors, and perhaps by the factory itself as a quality control check.

h) A project should be initiated to develop better field test and diagnostic methods, and interpretive guidelines. The controlled environment in the CMFERT facility is ideally suited for improving infrared, blower-door, and tracer-gas test methods.

i) In the factory observation phase of this study, DOE scientists worked closely with manufacturing engineers to integrate cost-effective energy improvements into the construction process. A project should be initiated to afford other manufacturers this opportunity, perhaps via CRADA agreements. 


\subsection{References}

1. Conner, C., A. Lee, R. Lucas, and Z. Taylor, Revision of the Energy Conservation Requirements in the HUD Manufactured Housing Construction and Safety Standards, Pacific Northwest Laboratories, Richland, Washington, Draft 1989.

2. Conner, C., and Z. Taylor, Calculation of Overall U-Values and Loads for Manufactured Homes, Pacific Northwest Laboratories, Richland, Washington, Draft 1990.

3. Judkoff, R., E. Hancock, E. Franconi, R. Hanger, and J. Weiger, Mobile Home Weatherization Measures: A Study of their Effectiveness, SERI/TR-254-3440, Solar Energy Research Institute, Golden, Colorado, 1988.

4. Judkoff, R., E. Hancock, and E. Franconi, Testing the Effectiveness of Mobile Home Weatherization Measures in a Controlled Environment: The NREL CMFERT Project, SERI/TP-254-3629, Solar Energy Research Institute, Golden, Colorado, 1990.

5. Judkoff, R., R. DeSoto, and E. Hancock, "CMFERT: Training and Testing of Mobile Home Retrofits," Home Energy, Volume 7, Number 1, Jan/Feb 1990.

6. Judkoff, R., "Mobile Home Retrofits Revisited: CMFERT Phase II," Home Energy, Volume 8, Number 1, Jan/Feb 1991.

7. Federal Register, Part III, Department of Housing and Urban Development, 24 CFR Part 3280, Manufactured Home Construction and Safety Standards; proposed rule, Feb. 24, 1992.

8. Cummings, J., J. Tooley, Jr., and N. Moyer, Investigation of Air Distribution System Leakage and Its Impact in Central Florida Homes, FSEC-CR-397-91, Florida Solar Energy Center, 1991.

9. American Society for Testing and Materials, Test Method for Determining Air Leakage Rate by Tracer Dilution - Standard E741, Philadelphia, Pennsylvania, 1983.

10. Claridge, D.E., and S. Bhattacharyya, "Measured Energy Impact of Infiltration in a Test Cell," Solar Engineering - Proceedings of the Eleventh Annual ASME Solar Energy Conference, American Society of Mechanical Engineers, New York, New York, 1989.

11. American Society for Testing and Materials, Test Method for Determining Air Leakage Rate by Fan Pressurization - Standard E779, Philadelphia, Pennsylvania, 1987

12. Judkoff, R., A Program to Calculate Effective Leakage Area from Blower Door Data and to Calculate Natural Infiltration Rate as a Function of Building and Weather-Specific Variables, BLOWDOR version 2.0, Solar Energy Research Institute, Golden, Colorado, 1991.

13. Sherman, M., D. Grimsrud, P. Condon, and B. Smith, Air Infiltration Measurement Techniques, LBL Report 10705, Lawrence Berkeley Laboratory, Berkeley, 1980.

14. Sherman, M., and M. Modera, "Comparison of Measured and Predicted Infiltration Using the LBL Infiltration Model," Measured Air Leakage of Buildings, Trechsel and Lagus, eds., American Society for Testing and Materials, Philadelphia, 1986. 
15. Conversation with John Tooley, Natural Florida Retrofit Inc., P.O. Box 560301, Montverde, Florida 34756-0301.

16. Memo from John Tooley (NFR) to Subrato Chandra (FSEC), 9/9/91.

17. American Society of Heating, Refrigerating and Air-Conditioning Engineers Inc., ASHRAE Standard 62-1989: Ventilation for Acceptable Air Quality, Atlanta. 


\subsection{Acknowledgments}

We thank Frank Walter of the Manufactured Housing Institute for his assistance in finding a manufacturer to participate in the project. We thank Walter Wells, President of Schult Homes, and his staff including Bob Godfrey, Pete Janatello, and Rod Cellmer for their cooperation. We also recognize Craig Connor of Pacific Northwest Lab, and Bill Freeborne and Don Fairman from HUD for their assistance and support. We also thank Subrato Chandra and John Tooley of the Florida Solar Energy Center for providing additional infrared, and airflow data to the project. We especially enjoyed the stimulating exchange of hypotheses with regard to the interpretation of these data sets.

This research was made possible with funding from the DOE/HUD collaborative, managed by Mr. Emest Freeman. The participation of the Florida Solar Energy Center was made possible with funding from the U.S. Department of Energy under the auspices of the Energy Efficient Industrialized Housing Project, Mr. George James, Program Manager. 


\begin{tabular}{|c|c|c|c|}
\hline Document Control Page & $\begin{array}{l}\text { 1. NREL Report No. } \\
\text { NREL/TP-253-4490 }\end{array}$ & $\begin{array}{l}\text { 2. NTIS Accession No. } \\
\text { DE92010576 }\end{array}$ & 3. Recipient's Accession No. \\
\hline \multirow{2}{*}{\multicolumn{3}{|c|}{$\begin{array}{l}\text { 4. Title and Subtitle } \\
\text { Thermal Testing of the Proposed HUD Energy Efficiency Standard for New } \\
\text { Manufactured Homes }\end{array}$}} & $\begin{array}{l}\text { 5. Publication Date } \\
\text { June } 1992\end{array}$ \\
\hline & & & 6. \\
\hline \multicolumn{3}{|c|}{$\begin{array}{l}\text { 7. Author(s) } \\
\text { Ronald D. Judkoff and Gregory M. Barker }\end{array}$} & $\begin{array}{l}\text { 8. Performing Organization Rept. No. } \\
\text { NREL/TP-253-4490 }\end{array}$ \\
\hline \multirow{2}{*}{\multicolumn{3}{|c|}{$\begin{array}{l}\text { 9. Performing Organization Name and Address } \\
\text { National Renewable Energy Laboratory } \\
1617 \text { Cole Blvd } \\
\text { Golden, CO } 80220\end{array}$}} & $\begin{array}{l}\text { 10. Project/Task/Work Unit No. } \\
\text { BE21.3050 }\end{array}$ \\
\hline & & & $\begin{array}{l}\text { 11. Contract (C) or Grant (G) No. } \\
\text { (C) } \\
\text { (G) }\end{array}$ \\
\hline \multirow{2}{*}{\multicolumn{3}{|c|}{$\begin{array}{l}\text { 12. Sponsoring Organization Name and Address } \\
\text { National Renewable Energy Laboratory } \\
1617 \text { Cole Blvd. } \\
\text { Golden, CO } 80401\end{array}$}} & $\begin{array}{l}\text { 13. Type of Report \& Period Covered } \\
\text { Technical Report }\end{array}$ \\
\hline & & & 14. \\
\hline \multicolumn{4}{|l|}{ 15. Supplementary Notes } \\
\hline \multicolumn{4}{|c|}{$\begin{array}{l}\text { Thermal testing of two manufactured homes was performed at the National Renewable Energy Laboratory's (NREL's) } \\
\text { Collaborative Manufactured Buildings Facility for Energy Research and Testing (CMFERT) environmental enclosure in the } \\
\text { winter and spring of } 1991 \text {. The primary objective of the study was to directly measure the thermal performance of two homes, } \\
\text { each built according to a proposed new U.S. Department of Housing and Urban Development (HUD) standard. Secondary } \\
\text { objectives were to test the accuracy of an accompanying compliance calculation method and to help manufacturers find cost- } \\
\text { effective ways to meet the new standard. Both homes performed within the standard. Their performance fell within } 8 \% \text { of } \\
\text { predictions based on the new draft HUD calculation manual. }\end{array}$} \\
\hline \multicolumn{4}{|c|}{$\begin{array}{l}\text { 17. Document Analysis } \\
\text { a. Descriptors } \\
\text { manufactured homes; mobile homes; energy conservation standards; thermal testing of buildings } \\
\text { b. Identifiers/Open-Ended Terms }\end{array}$} \\
\hline \multirow{2}{*}{\multicolumn{2}{|c|}{$\begin{array}{l}\text { 18. Availability Statement } \\
\text { National Technical Information Service } \\
\text { U.S. Department of Commerce } \\
\text { 5285 Port Royal Road } \\
\text { Springfield, VA } 22161\end{array}$}} & & $\begin{array}{l}\text { 19. No. of Pages } \\
32\end{array}$ \\
\hline & & & $\begin{array}{l}\text { 20. Price } \\
\text { A03 }\end{array}$ \\
\hline
\end{tabular}

Form No. 0069E (6-30-87) 